\title{
Determinants of Profitability in Banking Sector: Empirical Evidence from Bangladesh
}

\author{
Md. Abu Issa Gazi ${ }^{1, *}$, Md. Shahbub Alam², G. M. Anwar Hossain ${ }^{3}$, SM Nahidul Islam4, \\ Muhammad Khalilur Rahman ${ }^{5}$, Md. Nahiduzzaman ${ }^{3}$, Abu Ishaque Hossain ${ }^{4}$ \\ ${ }^{1}$ School of E-Commerce, Jiujiang University, Jiangxi, 332000, China \\ ${ }^{2}$ Department of Business Administration, Sonargaon University, Dhaka-1215, Bangladesh \\ ${ }^{3}$ Department of Finance and Banking, Islamic University, Kushtia-7003, Bangladesh \\ ${ }^{4}$ Department of Business Administration, The International University of Scholars, Dhaka-1212, Bangladesh \\ ${ }^{5}$ Faculty of Entrepreneurship and Business, Universiti Malaysia Kelantan, 16100 Pengkalan Chepa Kelantan, Malaysia
}

Received August 8, 2021; Revised October 20, 2021; Accepted November 11, 2021

\section{Cite This Paper in the following Citation Styles}

(a): [1] Md. Abu Issa Gazi, Md. Shahbub Alam, G. M. Anwar Hossain, SM Nahidul Islam, Muhammad Khalilur Rahman, Md. Nahiduzzaman, Abu Ishaque Hossain , "Determinants of Profitability in Banking Sector: Empirical Evidence from Bangladesh," Universal Journal of Accounting and Finance, Vol. 9, No. 6, pp. 1377-1386, 2021. DOI: 10.13189/ujaf.2021.090616.

(b): Md. Abu Issa Gazi, Md. Shahbub Alam, G. M. Anwar Hossain, SM Nahidul Islam, Muhammad Khalilur Rahman, Md. Nahiduzzaman, Abu Ishaque Hossain (2021). Determinants of Profitability in Banking Sector: Empirical Evidence from Bangladesh. Universal Journal of Accounting and Finance, 9(6), 1377-1386. DOI: 10.13189/ujaf.2021.090616.

Copyright $\odot 2021$ by authors, all rights reserved. Authors agree that this article remains permanently open access under the terms of the Creative Commons Attribution License 4.0 International License

\begin{abstract}
Bangladesh is a developing country. The vital role of banking sector in permanent, sustainable and continuous economic growth is undeniable. Bangladeshi banking sectors consist of private commercial banks, specialized banks, Islamic banks and public sector banks. Covering the period of 50 years banking sector Bangladesh has apparent serious changes in terms of growth of profitability and development which is the main concern of this study. The main objective of this research is to determine the factors affecting profitability in the banking sector of Bangladesh. The study attempts to investigate firms' specific factors and macroeconomics factors' impact on the profitability in the Bangladeshi banking sector. In this regard, 32 banks have been considered as sample and the scenario of these banks over the last 10 years has been observed (2011-2020). In this case, panel data research methodology has been used. OLS regression model is used to analyze data. Moreover, a general to specific modeling approach is used in this case. The result of this study reveals that both firms' specific variables (i.e. Equity to Asset Ratio, Deposit to Asset ratio, Debt to Equity Ratio, Loan to Deposit Ratio) and macroeconomic variable (GDP growth rate) have statistically significant impact on the profitability, represented by Return on Asset (ROA) and
\end{abstract}

Return on Equity (ROE). All the research findings are very useful to the investors, shareholders, bank's authority, policy makers, and government for the improvement of the performance in the banking sector of Bangladesh.

Keywords Profitability, Firms' Specific Variables, OLS Model, Banking Sector, Ratio

JEL Classifications: C20, C23, F62, G21

\section{Introduction}

Banking sector as a prominent financial institute contributes a vigorous development role of economy of a country [1, 2]. Among different financial sectors in Bangladesh, the main task of the banking industry is to turn the savings of the people into productive investments as well as development of living standard of the country's people [3]. Moreover, the economic activities as well as social activities are performed by the banking sector in Bangladesh after independent. Thus, it leads to economic growth of Bangladesh [4]. Except Bangladesh bank itself, there are 60 scheduled banks among these 42 private 
commercial banks and 6 state owned commercial banks providing banking services in Bangladesh [5]. Bangladesh bank is the supreme authority of maintenance of all the banks in Bangladesh [6]. Loan and advance (term loan, education loan, car loan, micro group credit, housing loan, micro credit enterprise etc.), mobile banking, ATM service, SME banking, SMS banking, internet banking, credit card, foreign currency account, locker service are the services of banking sector in Bangladesh [7]. Corporate banking, real-time online banking for corporate clients, loan syndication are also the services of banking sector in Bangladesh [8]. Since many years have passed and till now banking sector plays the most significant role for the country's development, hence it is important to evaluate the performance of the banking sector [2]. Profitability measurement is an important matter for financial institution. To achieve high profitability of banks' should have sound fund management, huge capital and risk bearing capability [9]. Undoubtedly, high profitability depends on liquidity adequacy, firm size growth rate; GDP, effective tax rate, interest rate, tangibility, assets turnover, capital structure and uniqueness [10] affect the profitability. Profitability indicates the financial performance of an institution. Thus, it is required to study the impact factors related to the profitability of a bank [11].

However, many studies in the past have identified the reasons why affected bank's profitability individually. But, very few earlier studies examined the banks' profitability. Consequently, the current study tries to inspect banking industry's profitability affecting factors. In the case panel data regression methodology has been used in examining banks' profitability. This study addresses of reviewing previous literatures and identifies the potential firms' specific and macroeconomic factors that may improve the banks' profitability in Bangladesh. Researchers believe that the results of the current study will be beneficial for investors, policymakers, banks' customers and the concerned authority.

\section{Literature Review}

In the present study the researchers have been reviewed a number of related literatures to find out the research gaps, applicable tools, and to arrive at meaningful conclusions, these are as follows;

Horobet, et al [12] studied determinants of bank profitability in CEE countries during 2009-2018 by applying the GMM panel data methodology. They found that inflation, budget balance, non-governmental credit, non-performing loan rates, capitalization rate and concentration rate negatively impact on the banking profitability. Islam and Rana [13] studied the determinants of bank profitability of Bangladesh's commercial bank during 2013-2017 relating fixed effect model for panel data method. They used three identical measures of profitability named ROA, ROE and NIM. Their findings demonstrated that earning variable and assets quality have a significant positive relationship with ROA but capital strength has not. They also found that earning and capital strength have a significant positive relationship with ROE, no significant impact of GDP rate, interest rate and inflation rate on bank's profitability. Sarwar, et al [14] studied 21 commercial banks belonging to Pakistan using E-views panel data method during 2006-2015. They found that bank size, capital adequacy ratio, management quality, asset management and liquidity have a significant impact on banks' profitability whereas no impact of interest on profitability. Sanyaolu, et al [15] the determinants of bank profitability of Nigerian's money deposit bank during 2008-2017 using fixed effect regression model. Their results exposed a relationship between inflation rate and profitability. Abdulkabir, et al [16] found that income divarication and bank size were positively correlated and capital structure and operating cost negatively correlated with ROA. Parvin, et al [17] studied the relationship between profitability and liquidity, and bank loan in Bangladesh during 2011-2015. They stated that deposit to asset ratio had a negative impact on ROA, and loan and bank size had a positive association with banks' profitability. Onofrei, et al [18] found from their study that inflation has no positive significant impact on banks profitability and found domestic non-governmental credit has positive impact on profitability of CEE region belonging 7 countries used panel data analysis and studied 96 banks. Cetin [19] found a positive impact of inflation on ROA in developing countries and a negative impact in developed countries using a fixed affects OLS during 2013-2015 for G20 countries. Uralov [20] studied determinants of bank profitability of central European countries during 1996-2017 and found a positive effect of economic growth on banks' profitability (ROA). Mahmud, et al [21] studied 15 commercial banks belonging to Bangladesh and found capital as positive relation to bank profitability. Hossain and Khalid [22] found that bank specific factors and market specific factors have influenced the bank profitability. Odusanya [23] studied the banking system of central and south eastern countries during 2008-2015 and found that GDP and INF are positively correlated with bank profitability. Mosharrafa and Islam [24] examined the bank profitability for Bangladesh during 2007-2017 found loan and efficient management had a positive relation with bank profitably. Hosen [25] performed a study in Bangladesh on 23 commercial banks and found that banks' specific factors like interest rate spread, capital adequacy ratio, credit risk, deposit growth, loan to deposit ratio, cost to income ratio and size of the bank significantly affect profitability of banks measured in terms of ROA and ROE. Moudud-Ul-Huq, Halim and Biswas [26] conducted a study on completion and profitability of banks from Middle East and North African countries during 2011-2017 found a significant negative 
impact of completion on bank's profitability. Lestaria, et al [27] found that there is a negative impact of liquidity and leverage on profitability (ROE) and positive impact of bank size on profitability.

Table 1. Review of Literature on Profitability

\begin{tabular}{|c|c|c|c|}
\hline Authors & Countries & Methods & Results \\
\hline Iskandar et al. [2] & Malaysia & \multirow{4}{*}{ Regression } & $\begin{array}{l}\text { Concluded that management efficiency, liquidity risk and credit risk have a } \\
\text { significant impact. }\end{array}$ \\
\hline Islam \& Rana [28] & \multirow{4}{*}{ Bangladesh } & & $\begin{array}{l}\text { Showed that earning variable, asset structure, capital strength and liquidity } \\
\text { have a significant positive impact on the profitability. }\end{array}$ \\
\hline Imtiaz et al. [29] & & & $\begin{array}{l}\text { Concluded that firm size, net interest margin, loan ratio and non-interest } \\
\text { income margin have a positive impact on profitability. }\end{array}$ \\
\hline Mosharrafa, et al. [24] & & & $\begin{array}{l}\text { Showed a constructive significant relationship between profitability of bank } \\
\text { and economic growth. }\end{array}$ \\
\hline Noman et al. [30] & & GMM & $\begin{array}{l}\text { Observed that actual interest rates have a negative effect on the profitability } \\
\text { whereas inflation rate, size and capital adequacy affect positively. }\end{array}$ \\
\hline Odusanya et al. [23] & Nigeria & \multirow{3}{*}{ Regression } & \\
\hline $\begin{array}{c}\text { Syathiri et al. } \\
\text { [31] }\end{array}$ & Indonesia & & are having a positive effect on profitability. \\
\hline $\begin{array}{l}\text { Brahmaiah and } \\
\text { Ranajee [32] }\end{array}$ & \multirow[b]{2}{*}{ India } & & $\begin{array}{l}\text { Found that Strength of equity capital, deposits to GDP ratio and Operational } \\
\text { efficiency have a positive effect on banks' profitability. }\end{array}$ \\
\hline $\begin{array}{l}\text { Mohanty and } \\
\text { Krishnankutty [33] }\end{array}$ & & \multirow[t]{2}{*}{ GMM } & $\begin{array}{l}\text { Revealed that capital solvency ratio and adequacy ratio have a positive } \\
\text { correlation with profitability whereas size, deposit ratio of loan, expense ratio, } \\
\text { and GDP growth have a significant negative impact. }\end{array}$ \\
\hline Ozili [34] & Africa & & \multirow{2}{*}{$\begin{array}{l}\text { Found that huge capital is related to the tendency of banks to increase their } \\
\text { profitability. }\end{array}$} \\
\hline Chowdhury [35] & UAE & GMM & \\
\hline Tan et al. [36] & \multirow{2}{*}{ China } & GMM & $\begin{array}{l}\text { Concluded that there is a negative association between debt risk and bank's } \\
\text { profit. }\end{array}$ \\
\hline Hu and Xie [37] & & SEM & $\begin{array}{l}\text { Calculated that the tendency to take risks effect positively on banks' } \\
\text { profitability. }\end{array}$ \\
\hline Uralov [20] & $\begin{array}{l}\text { European } \\
\text { Union }\end{array}$ & GCA & Found a positive relationship between GDP growth rate and profitability. \\
\hline Opoku et al. [38] & Ghana & \multirow{4}{*}{ Regression } & $\begin{array}{l}\text { Concluded that non-performing loans affect the banks' profitability } \\
\text { negatively. }\end{array}$ \\
\hline $\begin{array}{l}\text { Brahmaiah and } \\
\text { Ranajee [32] }\end{array}$ & India & & Exposed that, Profitability and economic growth have a positive correlation. \\
\hline Alzoubi [39] & Jordan & & $\begin{array}{l}\text { Concluded that equities to assets, bank size, cash to assets and deposits to } \\
\text { assets have a more significant impact on Islamic banks' profitability than } \\
\text { conventional banks, whereas securities to assets and loans to assets have a } \\
\text { more significant impact on conventional banks' profitability than Islamic } \\
\text { banks. }\end{array}$ \\
\hline Bhattarai [40] & Nepal & & $\begin{array}{l}\text { Showed that Capital adequacy ratio, Annual inflation rate and Exchange rate } \\
\text { have a positive impact on profitability. }\end{array}$ \\
\hline $\begin{array}{l}\text { Moudud-Ul-Huq et al. } \\
\text { [26] }\end{array}$ & Middle East & GMM & $\begin{array}{l}\text { A positive relationship between interest rates and bank profitability is } \\
\text { observed. }\end{array}$ \\
\hline $\begin{array}{c}\text { Sarwar, Bilal, et al. } \\
\text { [14] }\end{array}$ & Pakistan & \multirow{2}{*}{ Regression } & $\begin{array}{l}\text { Concluded that large amount of non-performing loans decreases banks' } \\
\text { profitability. }\end{array}$ \\
\hline Lestaria et al. [27] & Indonesia & & $\begin{array}{l}\text { Showed independent auditors have a significant effect on the banks' } \\
\text { profitability }\end{array}$ \\
\hline Ariyadasa et al. [41] & Sri Lanka & VECM & $\begin{array}{l}\text { Found that non-performing loans and interest rate have a negative impact on } \\
\text { banks' profitability. }\end{array}$ \\
\hline Horobet [13] & Syria & GMM & $\begin{array}{l}\text { They observed inflation and economic development rate have a positive } \\
\text { impact on profitability. }\end{array}$ \\
\hline $\begin{array}{l}\text { Aydemir and Ovenc } \\
{[42]}\end{array}$ & Turkey & \multirow{5}{*}{ Regression } & Showed that interest rate has a significant impact on the banks' profitability. \\
\hline $\begin{array}{l}\text { Regehr and Sengupta } \\
\text { ([43] }\end{array}$ & US & & $\begin{array}{l}\text { Found that inflation rate has a negative effect on the bank profitability } \\
\text { whereas bank size affects positively. }\end{array}$ \\
\hline Isah [44] & Hungary & & \multirow{3}{*}{$\begin{array}{l}\text { Exhibited that size of the bank has a positive significant impact on } \\
\text { profitability whereas overhead costs, liquidity and non-performing loans have } \\
\text { a significant negative impact. }\end{array}$} \\
\hline $\begin{array}{l}\text { Tabash et al. } \\
\text { [45] }\end{array}$ & Saudi Arabia & & \\
\hline $\begin{array}{c}\text { Islam \& Bhhuiyan } \\
\text { [46] }\end{array}$ & Bangladesh & & \\
\hline
\end{tabular}

*GMM = Generalized Method of Moment, * SEM= Structural Equation Modelling, *GCA= Granger Causality Analysis

Source: Authors' own explanations 
We can conclude from the results of previous studies that a sound banking system has a profound effect on the functioning of the real economy. The financial crisis of 2008 proves that when banks go into financial trouble, it has an adverse effect on the entire financial system (Budhathoki et al [47]. Determinants belonging to the banking and financial market group were often analysed by researchers and found to have a more significant impact on their banking profit ratio than macroeconomic factors. They impact on banking profits because of the differences of in the banking sector. The results of the time analysed are actually also affected by the previous condition. Similar results were found in pre-crisis and post-crisis studies used same determinants to analyse bank’s profitability (López et al [48]; Brei et al [49]; Global financial crisis positively affects the bank profitability (Abdullah and Tan [50]. The banking sector of Bangladesh faced various problems during the financial but was able to overcome it gradually. In particular the government also helps the effective role of investors to get out of this situation. On the basis of reviewed literature we postulate the following hypotheses

H1: Bank Size, Loan to Deposit Ratio, Inflation Rate and Domestic Product Growth Rate has no significant effect on profitability of banking sector in Bangladesh.

H2: Debt to Asset Ratio, Deposit to Asset Ratio, Equity to Asset Ratio and, Debt to Equity Ratio has no significant effect on profitability of banking sector in

\section{Bangladesh.}

Although a lot of research has been done on the banks' profitability in Bangladesh and all over the world, in recent times researchers have tried to carry out the present study with some new variables outside the conventional ones which is a novelty in this study. However, the current research seeks to find specific factors and macroeconomic factors that influence the profitability of Bangladesh's banking sector.

\section{Research Methods and Procedures}

\subsection{Data Collection}

Present study comprises of 59 scheduled banks as population that are in Bangladesh [6]. Considering the availability of data, from the total population, randomly selected 32 commercial banks. Past 10 years' data (secondary data) have been used in this study, which covers 2011 to 2020 and 320 observations were formed from panel data method.

\subsection{Variables}

To examine the reasons for affecting profitability of Bangladesh's banking industry; some selected variables were used (table-1).

Table 2. Conceptual framework of the study

\begin{tabular}{|c|c|c|c|c|}
\hline \multicolumn{5}{|c|}{ Determinants of Profitability } \\
\hline & & Variables & Formulas & Source \\
\hline \multirow{2}{*}{\multicolumn{2}{|c|}{$\begin{array}{l}\text { Dependent } \\
\text { Variables }\end{array}$}} & $\begin{array}{l}\text { ROA-Return on } \\
\text { Asset }\end{array}$ & $\frac{\text { Net profit after tax }}{\text { Total assets }}$ & Noman et al. [30]; Budhathoki et al [47] \\
\hline & & $\begin{array}{l}\text { ROE-Return on } \\
\text { Equity }\end{array}$ & $\frac{\text { Net profit after tax }}{\text { Total equity }}$ & $\begin{array}{l}\text { Noman et al.[30]; } \\
\text { López et al [48] }\end{array}$ \\
\hline \multirow{5}{*}{$\begin{array}{l}\text { Independent } \\
\text { Variables }\end{array}$} & \multirow{4}{*}{$\begin{array}{l}\text { Specific variables } \\
\text { of firm }\end{array}$} & $\begin{array}{l}\text { EAR-Equity to } \\
\text { Asset Ratio }\end{array}$ & $\frac{\text { Total equity }}{\text { Total asset }}$ & Brei et al [49] \\
\hline & & $\begin{array}{c}\text { Deposit to Asset } \\
\text { ratio (DTAR) }\end{array}$ & $\frac{\text { Total deposit }}{\text { Total asset }}$ & Tercero-Lucas [51] \\
\hline & & $\begin{array}{l}\text { Debt to Equity Ratio } \\
\text { (DER) }\end{array}$ & $\frac{\text { Total Liabilites }}{\text { Total Equity }}$ & Abdullah and Tan [50] \\
\hline & & $\begin{array}{l}\text { Loan to Deposit } \\
\text { Ratio (LDR) }\end{array}$ & $\frac{\text { Total loans }}{\text { Total Deposits }}$ & Regehr and Sengupta [43] \\
\hline & $\begin{array}{l}\text { Macroeconomic } \\
\text { Variables }\end{array}$ & $\begin{array}{l}\text { GDPGR-Gross } \\
\text { Domestic Product } \\
\text { Growth Rate }\end{array}$ & $\begin{array}{c}\text { Yearly percentage change in } \\
\text { the gross domestic Product } \\
\text { i.e. } \\
\left(\mathrm{GDP}_{\mathrm{n}}-\mathrm{GDP}_{\mathrm{n}-1} / \mathrm{GDP}_{\mathrm{n}-1}\right)\end{array}$ & $\begin{array}{l}\text { Islam and Bhhuiyan [46] Alzoubi [39]; } \\
\text { Opokuet al [38]; Bhattarai [40] }\end{array}$ \\
\hline
\end{tabular}

Source: Authors' own explanations 


\subsection{Model}

The regression model of Panel data has been used to investigate the specific aspect and macroeconomic components of banks that influence profitability. Panel data analysis consists of three types of extensive used models i.e. random-effects models, fixed effects and pooled ordinary least square (OLS). The definite assumptions like error term, intercept, coefficients regression [52]. Present study used Hausman test to find results between fixed effects specification and random effects specification. E-views econometric software was used to assess all models and tests. Breusch-Pagan Lagrange Multiplier Test was also used to verify the appropriateness of the models. However, in this regard, following regression models have been proposed:

Model-1:

$$
\begin{gathered}
\text { ROA }_{\mathrm{it}}=\alpha_{\mathrm{i}}+\beta_{1}(\mathrm{BS}) \\
\mathrm{it}^{+} \beta_{2}(\mathrm{DAR})_{\mathrm{it}}+\beta_{3}(\mathrm{DTAR})_{\mathrm{it}}+\beta_{4}(\mathrm{EAR})_{\mathrm{it}}+ \\
\beta_{5}(\mathrm{IR})_{\mathrm{it}}+\beta_{6}(\mathrm{GDPGR})_{\mathrm{it}}+u_{\mathrm{it}}
\end{gathered}
$$

Model-2:

$$
\begin{gathered}
\mathrm{ROE}_{\mathrm{it}}=\alpha_{\mathrm{i}}+\beta_{1}(\mathrm{BS})_{\mathrm{it}}+\beta_{2}(\mathrm{EAR})_{\mathrm{it}}+\beta_{3}(\mathrm{DER})_{\mathrm{it}}+\beta_{4}(\mathrm{LDR})_{\mathrm{it}}+ \\
\beta_{5}(\mathrm{IR})_{\mathrm{it}}+\beta_{6}(\mathrm{GDPGR})_{\mathrm{it}}+u_{\mathrm{it}}
\end{gathered}
$$

Where, $\alpha=$ Intercept of the model; $\mathrm{i}=$ Index of Banks; $\mathrm{t}=$ Time index

$\beta_{k}=$ Regression Coefficient to be estimated

ROA = Return on Asset; ROE = Return on Equity; BS =

Bank Size; DAR = Debt to Asset Ratio; DTAR = Deposit to Asset Ratio; EAR= Equity to Asset Ratio; DER= Debt to Equity Ratio; LDR = Loan to Deposit Ratio; IR = Inflation Rate and GDPGR=Gross Domestic Product Growth Rate.

\section{Analysis and Results}

\subsection{Descriptive Statistics}

According to the results of ROA and ROE being $0.9 \%$ and $1107 \%$ (mean value) respectively which indicates the performance of banking sector in Bangladesh based on profitability is not so good. Table 3 shows that positive mean values of all independent variables.

\subsection{Correlation Analysis}

Pearson's Correlation Coefficients are applied to determine the relationship between the variables used in this study (table-4). Multicollinearity problems occur when the correlation coefficient between variables exceeds 0.80 [53]. It is observed in the correlation matrix that the linearity problems do not exist in the explanatory variables (does not exceeds 0.80). The matrix shows that BS, EAR, DER, LDR, ROE are positively associated with ROA where as DTAR and GDPGR are negatively associated with ROA. Finally, EAR, LDR and ROA are positively associated with ROE whereas BS, DTAR, DER and

\begin{tabular}{|c|c|c|c|c|c|c|c|c|}
\hline Variables & BS & DTAR & EAR & ROE & ROA & DER & LDR & GDPGR \\
\hline BS & 1.0000 & -0.1235 & 0.3370 & -0.1215 & 0.1588 & 0.4111 & -0.0342 & 0.3829 \\
\hline DTAR & & 1.0000 & 0.3580 & -0.0094 & -0.0000 & -0.0988 & -0.3026 & 0.0872 \\
\hline EAR & & & 1.0000 & 0.0565 & 0.5296 & 0.1769 & -0.0663 & -0.0322 \\
\hline ROE & & & & 1.0000 & 0.4256 & -0.3193 & 0.1313 & -0.1873 \\
\hline ROA & & & & & 1.0000 & 0.0787 & 0.0533 & -0.1720 \\
\hline DER & & & & & & 1.0000 & -0.0628 & 0.0816 \\
\hline LDR & & & & & & & 1.0000 & 0.2029 \\
\hline GDPGR & & & & & & & & 1.0000 \\
\hline
\end{tabular}
GDPGR are negatively associated with ROE.

Table 3. Descriptive Statistics, using the observations 1 - 320

\begin{tabular}{|c|c|c|c|c|c|c|c|}
\hline Variables & Mean & Median & SD & Variables & Mean & Median & SD \\
\hline ROA & 0.00945 & 0.0106 & 0.0168 & DER & 12.3 & 11.4 & 8.22 \\
\hline ROE & 0.117 & 0.128 & 0.226 & LDR & 0.848 & 0.856 & 0.195 \\
\hline BS & 25.8 & 25.8 & 0.891 & GDPGR & 0.0654 & 0.0649 & 0.00673 \\
\hline DTAR & 0.812 & 0.801 & 0.397 & EAR & 0.0608 & 0.0778 & 0.144 \\
\hline
\end{tabular}

Table 4. Correlation coefficients, using the observations 1 - 320 


\subsection{Panel Data Analysis}

Hausman test, Breusch-Pagan Lagrange Multiplier (LM) and F-test have been used to choose an appropriate model of this study. Table 5 focuses firstly to choose F-test that has been conducted to indicate among pooled and fixed effects models.

Secondly, the LM test is applied to select suitable model among random and combined effects. Results reveal that the random effects models are chosen over pooled at the 5\% level of significant of chi-square values aimed at Model 1 and one percent (1\%) level intended for Model two (2). Thus, both F-test and LM test suggest fixed and random effects model are rejected pooled model. Finally, Hausman experiment was conducted to choose the model between static and random effects. According to the result, both models suggest for random effect model as the p-values of chi-square statistic are very high at the significant level of $5 \%$. Therefore, researchers concluded that random effect model is appositely used for both Model-1 (ROA-Return on Asset) and Model-2 (ROE-Return on Equity).

Table- 6 indicates the results of the random effects estimation for the bank profitability measured by ROA. In this model, five firms' specific variables i.e. Bank Size
(BS), Equity to Asset Ratio (EAR), Debt to Equity Ratio (DER), Load to Deposit Ratio (LDR) and Deposit to Asset Ratio (DTAR) have been used whereas one macroeconomic variable has been used (GDPGR- Gross Domestic Product Growth Rate).

The Models hysterics the data moderately having the adjusted $R 2$ value of $32.9 \%$. It implies that explanatory variables explain about 32 percent of the variability of the dependent variable. The Coefficient values of the independent variables are jointly statistically significant at the significant level of $1 \%$ where coefficient value of F-statistic is significant. Besides, the DW (Durbin-Watson) test value of this model is 1.94 which suggests that there is no autocorrelation based on the rule of thumb [54]. Hence, the overall fit of the model looks very good. Subsequently a number (three) of explanatory variables of this model are not significant; we might droplet these variables as of the model and re-guesstimate the model by using GSA (General Specific Approach) [55] for accomplishing the utmost efficient model.

Further, table- 6 shows that the results of re-estimation where all the explanatory variables i.e. DTAR, EAR and GDPR are used in re-estimation which are statistically significant at $1 \%$ level of significance.

Table 5. The Results of F, LM, and Hausman Tests

\begin{tabular}{|c|c|c|c|}
\hline \multicolumn{2}{|c|}{ Tests } & Model-1 & Model-2 \\
\hline \multirow{2}{*}{ F Test } & F Statistic & 2.57431 & 3.24878 \\
\cline { 2 - 4 } & P-value & 0.0098 & 0.0014 \\
\hline \multirow{2}{*}{ Breusch-Pagan Test } & Chi-Square statistic & 4.76738 & 10.8576 \\
\cline { 2 - 4 } & P-Value & 0.0290 & 0.000 \\
\hline \multirow{2}{*}{ Hausman Test } & Chi-Square statistic & 1.810105 & 7.1857 \\
\cline { 2 - 4 } & P-Value & 0.9363 & 0.3040 \\
\hline
\end{tabular}

Table 6. Random effects estimation results for bank profitability (measured by ROA)

\begin{tabular}{|c|c|c|c|c|}
\hline \multicolumn{5}{|c|}{ Dependent Variable: ROA } \\
\hline \multirow{2}{*}{ Variable } & \multicolumn{2}{|c|}{ Model-I } & \multicolumn{2}{|c|}{ Model-II } \\
\hline & Coefficient & P-value & Coefficient & P-value \\
\hline $\mathrm{C}$ & 0.028975 & 0.3168 & 0.033868 & 0.0003 \\
\hline BS & 0.000122 & 0.9186 & & \\
\hline EAR & 0.069260 & $0.0000^{* * *}$ & 0.069190 & $0.0000 * * *$ \\
\hline GDPGR & -0.372703 & $0.0246 * *$ & -0.334964 & $0.01 * * *$ \\
\hline LDR & 0.005099 & 0.2527 & & \\
\hline DER & $-5.72 \mathrm{E}-05$ & 0.5785 & & \\
\hline DTAR & -0.007561 & $0.0019 * * *$ & -0.008281 & $0.0001^{* * *}$ \\
\hline Observations & \multicolumn{2}{|c|}{320} & \multicolumn{2}{|c|}{320} \\
\hline Adjusted R-squared & \multicolumn{2}{|c|}{0.329077} & \multicolumn{2}{|c|}{0.331505} \\
\hline F-statistic & \multicolumn{2}{|c|}{27.07743} & \multicolumn{2}{|c|}{53.73052} \\
\hline Prob(F-statistic) & \multicolumn{2}{|c|}{$0.000000^{* * *}$} & \multicolumn{2}{|c|}{$0.000000^{* * *}$} \\
\hline Durbin-Watson & \multicolumn{2}{|c|}{1.939394} & \multicolumn{2}{|c|}{1.908772} \\
\hline
\end{tabular}

Note: ** $5 \%$ level of significant and *** $1 \%$ level of significant 
Table 7. Random effects estimation results for bank profitability (measured by ROE)

\begin{tabular}{|c|c|c|c|c|}
\hline \multicolumn{5}{|c|}{ Dependent Variable: ROE } \\
\hline \multirow{2}{*}{ Variable } & \multicolumn{2}{|c|}{ Model-I } & \multicolumn{2}{|c|}{ Model-II } \\
\hline & Coefficient & P-value & Coefficient & P-value \\
\hline $\mathrm{C}$ & 0.087568 & 0.8401 & 0.510091 & 0.0003 \\
\hline BS & 0.018263 & 0.3108 & & \\
\hline EAR & 0.147223 & 0.1408 & & \\
\hline GDPGR & -7.342786 & $0.0026^{* * *}$ & -6.499476 & $0.0020 * * *$ \\
\hline LDR & 0.167705 & $0.0129 * *$ & 0.155818 & $0.01^{* * *}$ \\
\hline DER & -0.009353 & $0.0000^{* * *}$ & -0.008186 & $0.0000 * * *$ \\
\hline DTAR & 0.002619 & 0.9428 & & \\
\hline Observations & \multicolumn{2}{|c|}{320} & \multicolumn{2}{|c|}{320} \\
\hline Adjusted R-squared & \multicolumn{2}{|c|}{0.139214} & \multicolumn{2}{|c|}{0.131931} \\
\hline F-statistic & \multicolumn{2}{|c|}{9.598570} & \multicolumn{2}{|c|}{17.16083} \\
\hline Prob(F-statistic) & \multicolumn{2}{|c|}{$0.000000 * * *$} & \multicolumn{2}{|c|}{$0.000000^{* * *}$} \\
\hline Durbin-Watson & \multicolumn{2}{|c|}{1.887545} & \multicolumn{2}{|c|}{1.863499} \\
\hline
\end{tabular}

The impact of firm specific and macroeconomic variables on the banks profitability measured by ROE is shown in table 7 .

The results of this model demonstrate that BS, DTAR, LDR and EAR have a positive impact on ROE-Return on Equity, whereas DER and GDPGR have a negative impact [46]. Among these variables, Debt to Equity Ratio (DER) and Gross Domestic Product Growth Rate (GDPGR) has a positive impact at $1 \%$ level of significance on ROE that is statistically significant $[16,19]$. Present study found that the LDR-Loan deposit Ratio has a positive significant impact on ROE. Durbin-Watson (DW) Test value indicates that the there is no auto-correlation based. Besides, F-statistics as coefficient value is significant. So, mostly fit of this model looks good. Like model-I, in order to attain the efficient model, researchers used General to Specific approach and found that all the explanatory variables (LDR, DER \& GDPGR) used in re-estimation that are statistically significant.

\section{Discussion}

The result of the Hausman test implies the fixed effect for testing the hypothesis is the appropriate model. In this model bank size, loan as the determinants of profitability is found positively influence on banks' profitability. Base on the results of table-7, bank size has positively affected the profitability (ROA) but negatively affect the ROE. Budhathoki et al. [47]; Sarwar, et al [14]; Abdulkabir, et al [19]; Horobet, et al [12] found same results of impact of bank size on productivity. Large scale bank has benefited more and can reduce management cost and risk and profit will increase significantly. Adversely, few research results showed that bank size has no significant impact on productivity and ROE i. e. Imtiaz [19], Brei et al [49], Isah [44]. Their study revealed the higher size of bank reduces the return on equity and net interest margin is also influenced by bank's size. Loan to deposit ratio has been found to have a positive significant influence on productivity. Several studies have been conducted on relationship between loan profitability (e.g. Kajola et al [56]; Okere et al [57] and found similar findings of the present study. Alternatively some studies found reverse results that indicated there is no impact of loan on profitability e.g. Opoku et al [38]; Ariyadasa et al [41]Tabash et al [45]; Annor and Obeng [58], Kani [59]; But in most cases are found positive impact. Present study showed that the inflation rate has no positive impact on productivity. Few studies have proved the similar result like Bhattarai [40], ] Lestaria et al [27], Sukmana R., Febriyati [55], inflation on of determinates of profitability of bank that with induce high volume of bank's loan which is affected bank profitability. Table 7 showed that GDP growth rate has a positive impact on banks profitability [56]. Several studies found a significant positive and negative impact of GDP on productivity i.e. Abdullah and Tan [50]. As a microeconomic factor, GDP had a positive significant relationship to bank profitability Several studies e. g. Abdullah and Tan [50]; Kajola et al [57]; Aykut [60]; and Natalia et al [61] which confirmed the findings of the present study. Null hypothesis (H1) no significant positive effect of bank size, loan to deposit ratio, inflation rate and domestic product growth rate on profitability of banking sector in Bangladesh is hereby rejected. The results demonstrate (Table-6) that bank size, Equity to Asset Ratio -EAR and Loan to Deposit Ratio -LDR have a positive impact on ROA [20,55], whereas DTAR, DER and GDPGR have a negative association with ROA. According to the result, fixed effects models are chosen over pooled as 
in $\mathrm{F}$ statistics the $\mathrm{P}$ value for both models are very low which reject null hypothesis (H2) at 1\% level of significant. Among these variables, Equity to Asset Ratio (EAR) and Deposit to Asset ratio (DTAR) are statistically significant $[30,31]$ at $1 \%$ level of significance on ROA- and have significant impact of GDPGR-Gross Domestic Product Growth Rate on ROA- Return on Asset at 5\% level of significance. Several researchers $[8,12,15]$ found same type of findings. Tan and Floros [36], Ariyadasa et al. [41], Alzoubi [39], Mohanty and Krishnankutty [33] also confirmed the same type of findings. As to the firms' specific variables (EAR, DER, LDR, DTAR) none has been found individually wield significant effect on banks' profitability. Both EAR and LDR have a positive significant effect on ROA, whereas DER and DTAR exert a negative effect on profitability. On the other hand, DTAR, LDR and EAR have a positive significant effect on ROE which indicates that the greater effect on productivity. Arising from the findings we can reject null hypothesis (H2) of no significant positive effect of EAR, DER, DTAR on profitability of banking sector in Bangladesh

\section{Conclusions}

Profitability helps to justify the impact of bank's financial success and growth trends. Thus, the factors affecting the banks' profitability are important to analyze. The present study seeks to examine the reasons for the profitability of the banking sector in Bangladesh, using 32 companies as sample for the period of ten years (2011-2020). In this regard, general to specific modeling approach has been adopted. Profitability analysis helps to understand the phenomena of sound and solvent financial position of an organization. The results reveal that some firms' specific variables and one macroeconomic variable have a statistically significant impact on the profitability that represented by ROA (Return on Asset) and ROE (Return on Equity). For measuring profitability Return on Assets-ROA, Return on Equity-ROE, Earnings per Share-EPS, Price-Earnings Ratio-P/E Ratio and Net Profit Ratio-NPR has been used. Present study shows that there is a significant difference in ROA, ROE, P/E Ratio and NPR in banking sector of Bangladesh. By using the results and findings of the present study policy makers of financial sectors and bank's authority would be able to formulate appropriate strategies to increase the performance of the banking sector in Bangladesh. Moreover, investor will be able to make informed decisions about investing and selecting bank stocks for their portfolios. The government and regulatory authority will be to take necessary steps to improve the financial performance of the Bangladesh banking sector. Finally, the study recommends that further investigations and research can be steered by using more classy research methodologies, additional samples, and more respondents.

\section{REFERENCES}

[1] Babu D.G.S., "Role of financial system in economic development of a country", International Journal of Multidisciplinary Research and Development, vol. 5, no. 8, pp. 100-107, 2018.

[2] Iskandar A.S., Yahya N. C., Wahid Z. A., "Determinants of Commercial Banks' Profitability in Malaysia”, Journal of Entrepreneurship and Business, vol.7, no. 1, pp.27-39, 2019.

[3] Rahaman M. A., Ali M. J., Taru R. D., Mamoon Z. R., ASHEQ A. A., "Understanding the Entrepreneurial Intention in the Light of Contextual Factors: Gender Analysis”, Journal of Asian Finance, Economics and Business, vol. 7, no. 9, pp. 639-647, 2020. doi:10.13106/jafeb.2020.vol7.no9.639

[4] Gazi M. A. I., Rahaman M.A., Hossain G.M.A. Ali M.J., Mamoon Z. R., "An Empirical Study of Determinants of Customer Satisfaction of Banking Sector: Evidence from Bangladesh", The Journal of Asian Finance, Economics, and Business, vol. 8, no. 2, pp. 497-503, 2021. https://doi.org/10.13106/JAFEB.2021.VOL8.NO2.0497

[5] Bangladesh Bank., "Bank and Financial System”. Retrieved from Bangladesh Bank, Central Bank of Bangladesh, https://www.bb.org.bd/fnansys/bankfi.php (accessed Jan. 09, 2021).

[6] Gazi M. A. I., Rahaman M.A., Waliullah S. S. A., Ali M. J., Mamoon Z. R., Financial "Performance of Converted Commercial Banks from Non-Banking Financial Institutions: Evidence from Bangladesh, The Journal of Asian Finance, Economics, and Business”, vol. 8, no. 2, pp. 923-931, 2021.

https://doi.org/10.13106/JAFEB.2021.VOL8.NO2.0923

[7] Trad N., Trabelsi M. A., Goux J. F., "Risk and profitability of Islamic banks: A religious deception or an alternative solution”, European Research on Management and Business Economics, vol. 23, no. 1, pp. 40-45, 2017.

[8] Rahaman M. A., Ali M. J., Kejing Z., Taru R. D., Mamoon Z. R., "Investigating the Effect of Service Quality on Bank Customers' Satisfaction in Bangladesh”, The Journal of Asian Finance, Economics and Business, vol.7, no.10, pp.823-829, 2020. https://doi.org/10.13106/jafeb.2020.vol7.n10.823

[9] Rahayuningsih S., Matulessy A., Rini R. A. P, Pandin M. G. R., "The local government transformation, the big five personality and anxiety”, Opcion, vol. 35, no. 88, pp. 759-770, 2019.

[10] Chandra T., Chandra, S., Wijaya E., Chandra J., Ng M., "Co-determination of Capital Structure and Profitability: An Empirical Test of Indonesia Stock Exchange”, Industrial Engineering \& Management Systems, vol. 19, no.3, pp.561-575, 2020.

doi : https://doi.org/10.7232/iems.2020.19.3.561

[11] Rahaman M. A., Ali M. J. Wafik H. M. A., Mamoon Z. R., Islam M.M., "What Factors Do Motivate Employees at the Workplace? Evidence from Service Organizations”, Journal of Asian Finance, Economics and Business, vol. 7, no. 12, pp. 515-521, 2020. doi:10.13106/jafeb.2020.vol7.no12.515

[12] Horobet, Alexandra, Radulescu,M., Belascu, L., Dita, S.M., 
"Determinants of Bank Profitability in CEE Countries: Evidence from GMM Panel Data Estimates” Journal of Risk and Financial Management 14: 307, 2021. https://doi.org/10.3390/jrfm14070307

[13] Shafiqul Islam, S., Rana,M. S., "Determinants of Bank Profitability: Evidence from Commercial Banks of Bangladesh," Journal of Asian Business Strategy, Asian Economic and Social Society, vol. 9(2), pages 174-183, 2019.

[14] Sarwar, Bilal, et al. "Internal and External Determinants of Profitability: A Case of Commercial Banks of Pakistan." Paradigms, vol. 12, no. 1, pp. 38, 2018.

[15] Sanyaolu W. A., Siyanbola T. T., Ogunmefun G. T., Makinde A. B., "DETERMINANTS OF PROFITABILITY OF NIGERIAN DEPOSIT MONEY BANKS”, Economic Review Journal of Economics and Business, Vol. XVII, Issue 1, pp. 47-62, 2019.

[16] Abdulkabir, S. A., Olutokunbo,O. T., Lawal, O. A., "Influence of Internal Factors on the Financial Performances: An Empirical Study on Nigerian Deposit Money Banks, Volume 3 Issue 12, pp. 212, 2020.

[17] Parvin, S., Chowdhury, A. N. M. M. H., Siddiqua, A., Ferdous, J., "Effect of Liquidity and Bank Size on the Profitability of Commercial Banks in Bangladesh”, Asian Business Review, 9(1), pp. 7-10, 2019. https://doi.org/10.18034/abr.v9i1.219

[18] Onofrei, Mihaela, Bostan,I., Roman, A., Firtescu, B. N., "The determinants of commercial bank profitability in CEE countries”, Romanian Statistical Review, vol.2, pp. 33-46, 2018.

[19] Cetin, Huseyin., "Inflation and Bank Profitability: G20 Countries Banks Panel Data Analysis” Paper presented at 2019 International Conference on Management Science and Industrial Engineering, Phuket, Thailand, May 24; pp. 16872, 2019.

[20] Uralov, S., (2020). “The Determinants of Bank Profitability: A Case of Central European Countries”, International Journal of Finance and Accounting, Vol. 8, Issue.3, pp.08-16. 2020.

[21] Mahmud, K., Mallik, A., Imtiaz, M. F., Tabassum, N., " Determinants of bank profitability; a case study", International Journal of Managerial Studies and Research (IJMSR), Volume 4, Issue 7, PP 67-74, 2016.

[22] Hossain, H., Khalid, M.S., "Determinants of Bank Profitability before and during Crisis: Evidence from Bangladesh", International Journal of Finance and Accounting, vol. 7(5), pp. 142-146, 2018. DOI: 10.5923/j.ijfa.20180705.02

[23] Odusanya, I.A., Yinusa, O.G., Ilo, B.M., "Determinants of firm profitability in Nigeria: Evidence from Dynamic Panel Models”, SPOUDAI Journal of Economics and Business, vol. 68(1), pp. 43-58, 2018.

[24] Mosharrafa, R.A., Islam, M. S., "What Drives Bank Profitability? A Panel Data Analysis of Commercial Banks in Bangladesh", " International Journal of Finance \&Amp; Banking Studies (2147-4486), Vol. 10(2), pp. 96-110, 2021. https://doi.org/10.20525/ijfbs.v10i2.1236
[25] Hosen, M. Z., "Internal Factors Influencing the Profitability of Commercial Banks in Bangladesh. International Journal of Economics and Financial Research, vol. 6(7), pp. 192-200, 2020.DOI:https://doi.org/10.32861/ijefr.67.192.2 00

[26] Moudud-Ul-Huq, S., Halim, M. A., Biswas, T., "Competition and Profitability of Banks: Empirical evidence from the Middle East \& North African (MENA) Countries”, Journal of Business Administration Research, Volume 03, Issue 02, pp.26-37, 2020. DOI: https://doi.org/10.30564/jbar.v3i2.1807

[27] Lestaria, H.S., Tariganb, G.G., Pohan, L.A., "The Effect of Liquidity, Leverage and Bank's Size of the Profitability Conventional Banks Listed on Indonesia Stock Exchange”, Jurnal Manajemen (Edisi Elektronik), Volume 12, Issue 2, Pages. 26-39, 2021.http://dx.doi.org/10.32832/jm-uika.v12 i2.3946

[28] Islam S., Rana M. S., "Determinants of Bank Profitability: Evidence from Commercial Banks of Bangladesh”, Journal of Asian Business Strategy, vol. 9, no. 2, pp. 174-183, 2019.

[29] Imtiaz M. F., Mahmud K., Faisal M. S., "The Determinants of Profitability of Non-bank Financial Institutions in Bangladesh”, International Journal of Economics and Finance, vol. 11, no. 6, pp. 25-32, 2019.

[30] Noman A. H. M., Chowdhury M. M., Jahan C. S., Kabir M. J., Pervin S., "The Effect of Bank Specific and Macroeconomic Determinants of Banking Profitability: A Study on Bangladesh”, International Journal of Business and Management, vol.10, no. 6, pp. 287-97, 2015.

[31] [31] Syathiri A., Anshori A., Sukmana R., "Determinant of Indonesian Islamic and Conventional Banks’ Profitability”, Industrial Engineering \& Management Systems vol.19, no. 3, pp. 538-542, 2020.

DOI :https://doi.org/10.7232/iems.2020.19.3.538

[32] Brahmaiah B., Ranajee., "Factors influencing profitability of banks in India”, Theoretical Economics Letters, vol. 8, no. 14, pp. 3046-3061, 2018.

[33] Mohanty B. K., Krishnankutty R., "Determinants of Profitability in Indian Banks in the Changing Scenario", International Journal of Economics and Financial Issues, vol. 8, no. 3, pp. 235-240, 2018.

[34] Ozili P. K., "Bank Profitability and Capital Regulation: Evidence from Listed and non-Listed Banks in Africa”, Journal of African Business, vol. 18, no. 2, pp. 143- 168, 2016.

[35] Chowdhury R. H., "Equity capital and bank profitability: Evidence from the United Arab Emirates", Afro-Asian Journal of Finance and Accounting, vol. 5, no. 1, pp. 1-20, 2015.

[36] Tan A. Y., Floros C., Anchor J. R., "The Profitability of Chinese banks: Impacts of risk, competition and efficiency”, Review of Accounting and Finance, vol. 16, no. 1, pp. 86-105, 2016.

[37] Hu T., Xie, C., “Competition, Innovation, Risk-Taking, and Profitability in the Chinese Banking Sector: An Empirical Analysis Based on Structural Equation Modeling”, Discrete Dynamics in Nature and Society, vol. 6, pp. 1-10, 2016. 
[38] Opoku R. T., Angmor P. L., Boadi L. A., "Credit Risk and Bank Profitability: Evidence from Ghana Stock Exchange”, Journal for Studies in Management and Planning, vol. 2. no. 3, pp. 89-96, 2016.

[39] Alzoubi T. "Determinants of bank profitability: Islamic versus conventional banks”, Banks and Bank Systems, vol. 13, no. 3, pp. 106-113, 2018.

[40] Bhattarai B. P., "Impact of bank specific and macroeconomic variables on performance of Nepalese Commercial Banks”, Global Review of Accounting and Finance, vol. 9, no. 1, pp. 35-53, 2018.

[41] Ariyadasa C., Selvanathan E. A., Siddique M. A. B., Selvanathan S., "On the profitability of commercial banks: The Sri Lankan case”, Applied Economics, vol. 49, no. 21, pp. 1-11, 2016.

[42] Aydemir R., Ovenc G., "Interest rates, the yield curve and bank profitability in an emerging market economy”, Economic Systems, vol. 40, no. 4, pp. 670-82, 2016.

[43] Regehr K., Sengupta R., "Has the Relationship between Bank Size and Profitability Changed"? Economic Review-Federal Reserve Bank of Kansas City, vol. 101, pp. 49-72, 2016.

[44] Isah S., "Determinants of Commercial Banks’ Profitability. Evidence from Hungary”, Acta Universitatis Agriculturae et Silviculturae Mendelianae Brunensis, vol. 66, no. 5, pp. 1325-1335, 2018.

[45] Tabash M. I., Albugami M. A., Salim, M., Akhtar, A., "Service quality dimensions of E-retailing of Islamic banks and its impact on customer satisfaction: An empirical investigation of kingdom of Saudi Arabia”, Journal of Asian Finance, Economics and Business, vol. 6, no. 3, pp. 225-234, 2019. doi. org/10.13106/jafeb.2019.vol6.no3.225

[46] Islam A. K. M., Bhhuiyan A. B., "Determinants of the Effectiveness of Internal Shariah Audit: Evidence from Islamic Banks in Banglades”, The Journal of Asian Finance, Economics, and Business, vol. 8, no. 2, pp. 223-230, 2021. doi.org/10.13106/JAFEB.2021.VOL8.NO2.0223

[47] Budhathoki P.B., Rai C.K., Lamicchane P.L., Bhattarai G., Rai A., "The Impact of liquidity, leverage and total size on bank's profitability: Evidence from Nepalese commercial banks”, Journal of Economic and Business, 3(2), 545-555, 2020.

[48] López J.A., Rose A.K., Spiegel M.M., "Why have negative nominal interest rates had such a small effect on bank performance? Cross country evidence” European Economic Review forthcoming, Volume 124, 103402, 2020. https://doi.org/10.1016/j.euroecorev.2020.103402

[49] Brei M., Borio C., Gambacorta L., "Bank intermediation activity in a low-interest-rate environment”, Economic Notes, forthcoming, 2020.

https://doi.org/10.1111/ecno.12164

[50] Abdullah N., Tan Y., "Profitability of commercial banks revisited: new evidence from oil and non-oil exporting countries in the MENA region”, Investment Management and Financial Innovations, 14, 3, 62-73, 2017.

[51] Tercero-Lucas, D., "Non-standard monetary policies and bank profitability: the case of Spain” Working Paper, 2020. https://doi.org/10.1002/ijfe.2535

[52] Kennedy P., “A guide to econometrics” Malden, Massachusetts: Blackwell Publishing, 2008.

[53] Field A., "Discovering Statistics Using SPSS”, 3rd edition. London: Sage Publications, 2009.

[54] Hendry D. F., "Epilogue: The success of general-to-specific model selection" Chapter 20. In D. F. Hendry (Ed.), Econometrics: Alchemy or Science? Essays in Econometric Methodology, Oxford University Press, Oxford, 2000, pp. 467- 490 .

[55] Sukmana R., Febriyati, N. A., "Islamic banks vs conventional banks in Indonesia: An analysis on financial performances”, Jurnal Pengurusan, vol. 47, pp. 81-90, 2016.

[56] Kajola S.O., Olabisi J., Ajayi J.A., Agbatogun T.O., "Determinants of profitability in Nigerian listed Deposit Money Banks.Journal of Economics and Business Research. 24, pp. 89-109, 2018.

[57] Alshatti A.S., "The effect of credit risk management on financial performance of Jordanian commercial banks", Investment Management and Financial Innovations, 12(1\&2), pp. 338-345, 2015.

[58] Okere W., Isiaka M.A., Ogunlowore A.J., "Risk management and financial performance of deposit money banks in Nigeria”, European Journal of Business, Economics and Accountancy. 6(2), pp. 30-42, 2018.

[59] Annor E.S., Obeng F.S., "Impact of credit risk management on the profitability of selected commercial banks listed on the Ghana stock exchange" Journal of Economics, Management and Trade. 20(2), pp. 1-10, 2017.

[60] Kani S., "Credit risk and banks performance: Evidence from WAEMU countries” IOSR Journal of Economics and Finance. 8(1), pp. 5-11, 2017.

[61] Natalia V. Trusova, Leonid V. Melnyk, Zhanna S. Shilo, Oleksandr S. Prystemskyi, "Credit-Investment Activity of Banks of the Ukraine: Financial Globalization, Risks, Stabilization," Universal Journal of Accounting and Finance, Vol. 9, No. 3, pp. 450 - 468, 2021. DOI: 10.13189/ujaf.2021.090320. 